\title{
A SYNOPSIS OF THE GENUS AETHRA LATREILLE, 1816 (DECAPODA, BRACHYURA, PARTHENOPIDAE)
}

\author{
BY \\ PETER K. L. NG \\ Department of Biological Sciences, National University of Singapore, \\ 10 Kent Ridge Crescent, Singapore 119260, Republic of Singapore
}

\begin{abstract}
A synopsis to the parthenopid genus Aethra Latreille, 1816, is provided. The nomenclatural history of the genus is clarified and several problems resolved. Four species are recognized: A. scruposa (Linnaeus, 1764), A. scutata Smith, 1869, A. edentata Edmondson, 1951, and A. seychellensis Takeda, 1975. All are figured and a key is provided for their identification. New records for A. scruposa and A. edentata are also provided.
\end{abstract}

\section{RÉSUMÉ}

Un synopsis du genre de Parthenopidae, Aethra Latreille, 1816 est fourni. L'histoire de la nomenclature du genre est clarifiée et plusieurs problèmes sont résolus. Quatre espèces sont reconnues: A. scruposa (Linnaeus, 1764), A. scutata Smith, 1869, A. edentata Edmondson, 1951, et A. seychellensis Takeda, 1975. Toutes sont figurées et une clé d'identification de ces quatre espèces est donnée. De nouvelles récoltes de A. scruposa et $A$. edentata sont également signalées.

\section{INTRODUCTION}

The Indo-Pacific parthenopid genus Aethra Latreille, 1816, is currently represented by four species, viz., A. scruposa (Linnaeus, 1764) (type species by monotypy); A. scutata S. I. Smith, 1869; A. edentata Edmondson, 1951; and A. seychellensis Takeda, 1975.

The best known and most widely distributed species is A. scruposa which has been reported from a wide area from the Indian to the western Pacific Ocean. Aethra scutata has been reported from various localities along the Pacific coast of America. The other two Aethra species are known only from their type localities. Aethra edentata was described from two small specimens from Hawaii and was not reported again until recently ( $\mathrm{Ng} \&$ Takeda, 1998). Aethra seychellensis is known only from one specimen collected from the Seychelles. 
The present note serves to provide a synopsis of the taxonomy of the genus Aethra. The terms used here essentially follow those used by Garth (1958). The abbreviations G1 and G2 are used for the male first and second pleopods, respectively. Measurements are of the carapace width and length, respectively. Specimens examined are deposited in the Bernice P. Bishop Museum (BPBM), Honolulu; National Science Museum, Tokyo (NSMT); National Museum of Natural History (USNM), Smithsonian Institution, Washington, D.C.; Zoological Reference Collection (ZRC), National University of Singapore; and the Nationaal Natuurhistorisch Museum (ex Rijksmuseum van Natuurlijke Historie, RMNH), Leiden.

\section{TAXONOMY}

\section{PARTHENOPIDAE MacLeay, 1838}

Aethra Latreille [in Cuvier], 1816

Oethra Latreille, 1816a: 24; Lamarck, 1818: 264; H. Milne Edwards, 1834: 370; Alcock, 1895: 284; Flipse, 1930: 20, 81.

Aethra Latreille, 1816b: 174; Latreille, 1816: 602; Rathbun, 1897: 167; Rathbun, 1925: 550.

Remarks. - Allegedly, the name Aethra was first used by Latreille (1816) when he briefly noted that "Mais il en est, telles que le Cancer scruposus Linnaeus (Herbst, Canc, tab. 53, fig. 4-5), et la parthénope voûtée de Fabricius (Herbst, ibid., tab. 13, fig. 79-80), où le test est aplati, très-raboteux, comme celui des araignées de mer, etc., et où le second article des pieds-mâchoires extérieurs est presque carré, sans finir en pointe. Ces espèces-ci composent le genre AEthre, AEthra, du docteur Léach. (L.)". Not surprisingly, most subsequent authors credit the name to Leach. Following the Code strictly, however, the authorship clearly belongs only to Latreille, as the description was done by Latreille, not by Leach, although it is probable that the genus was first recognized by Leach and its definition may have been conveyed to Latreille by Leach (see also Ng, 1994). The citation for the genus should thus be Aethra Latreille, 1816.

The next time the name Aethra was used was by Latreille in the third volume of Cuvier's "Règne Animal", but this time, it was spelled with an "O", i.e., Oethra. In volume four of Cuvier's "Règne Animal", however, Latreille inexplicably reverted back to the original spelling for the name, i.e., Aethra. The dates for the first four volumes of Cuvier's "Règne Animal" have often been cited as 1817 , but the available evidence suggests that all four volumes of Cuvier's "Règne Animal" had, in fact, already been published by November 1816 (and possibly even earlier) (see Roux, 1976: 31). This creates a problem because 
Latreille's account of the genus in "Nouveau Dictionnaire" was published on December 14, 1816 (Mathews, 1911: 18).

The above information thus creates a problem with both the spelling and authorship for Aethra. Contrary to what is generally assumed, viz., Aethra Latreille [in Cuvier], 1816, and Oethra Latreille [in Cuvier], 1816, both predate Aethra Latreille, 1816, by at least a month, and thus have priority. Aethra Latreille [in Cuvier], 1816, and Oethra Latreille [in Cuvier], 1816, were both published in the same work, and as such, are both available names. Rathbun (1897: 167), in her comments on brachyuran nomenclature, commented very briefly that the spelling for the genus should be "... Aethra not Oethra". On the basis of Article 24a of the present code of zoological nomenclature (ICZN, Article 24a), Rathbun's (1897) action is valid as, in effect, she acted as the First Reviser. Aethra Latreille [in Cuvier], 1816, thus has priority over Oethra Latreille [in Cuvier], 1816. In turn, Aethra Latreille [in Cuvier], 1816, has precedence over Aethra Latreille, 1816.

Guinot (1966) has commented on the affinities of Aethra and argued for the inclusion of Osachila, Hepatus, Hepatella, and Actaeomorpha within a "parthenooxystomien" group within the Parthenopidae. Into this group would also have to be included the genus Sakaila Manning \& Holthuis, 1981.

\section{Aethra scruposa (Linnaeus, 1764) (fig. 1)}

Cancer scruposus Linnaeus, 1764: 450.

Aethra scruposa Alcock, 1895: 284; Stimpson, 1907: 32; Dai et al., 1986: 158, pl. 21 fig. 6, text-fig. 89 no. 2; Dai \& Yang, 1991: 175, pl. 21 fig. 6, text-fig. 89 no. 2; Guinot, 1966: 754, fig. 11; Guinot, 1967: 837, figs. 39, 40; Sakai, 1976: 289, pl. 97 fig. 3; Colin \& Arneson, 1996: 217.

Oethra scruposa Flipse, 1930: 81.

[For remaining synonymy, see Alcock, 1895; Dai \& Yang, 1991.]

Material examined. - 1 male, 86.5 by $60.4 \mathrm{~mm}$, ZRC 1993.118 ; Trincomali reefs, northeastern Sri Lanka; obtained P. K. L. Ng, coll. local fishermen, 1992; 1 female, 80.6 by $57.0 \mathrm{~mm}$, ZRC 1997.440; Aitutaki Islands, Cook Islands, location 261, in sand, less than $2 \mathrm{~m}$ depth, outer reef flat of fringing reef, off west end of airfield of main island; coll. B. Holthuis \& G. Paulay, 27 October 1986; 1 female, 93.5 by 65.7 mm, BPBM; location 262, Aitutaki Islands, Cook Islands, location 261, buried in sand, $1.5 \mathrm{~m}$ depth, outer lagoon along middle of southern barrier reef; coll. B. Holthuis \& G. Paulay, 29 October 1986; 1 male, USNM Acc. No. 359474; Facpi Point, Guam, under rock, 30 feet depth; coll. V. E. Tyndzik, 22 June 1984; 1 female, USNM Acc. No. 359474; Apra Harbour, Glass Breakwater, Guam; coll. S. Rideout, 1 June 1974; 1 female, USNM Acc. No. 359474; Gun Beach, under rock on outer reef slope, 12 feet depth, Guam; coll. T. Potter, 8 November 1985; 1 juvenile male, 34.2 by $24.1 \mathrm{~mm}$ (dried), ZRC; in intake channel of marine laboratory, University of Guam, 3 feet depth, Pogo Bay, Guam, coll. D. Wooster, 25 March 1974. 


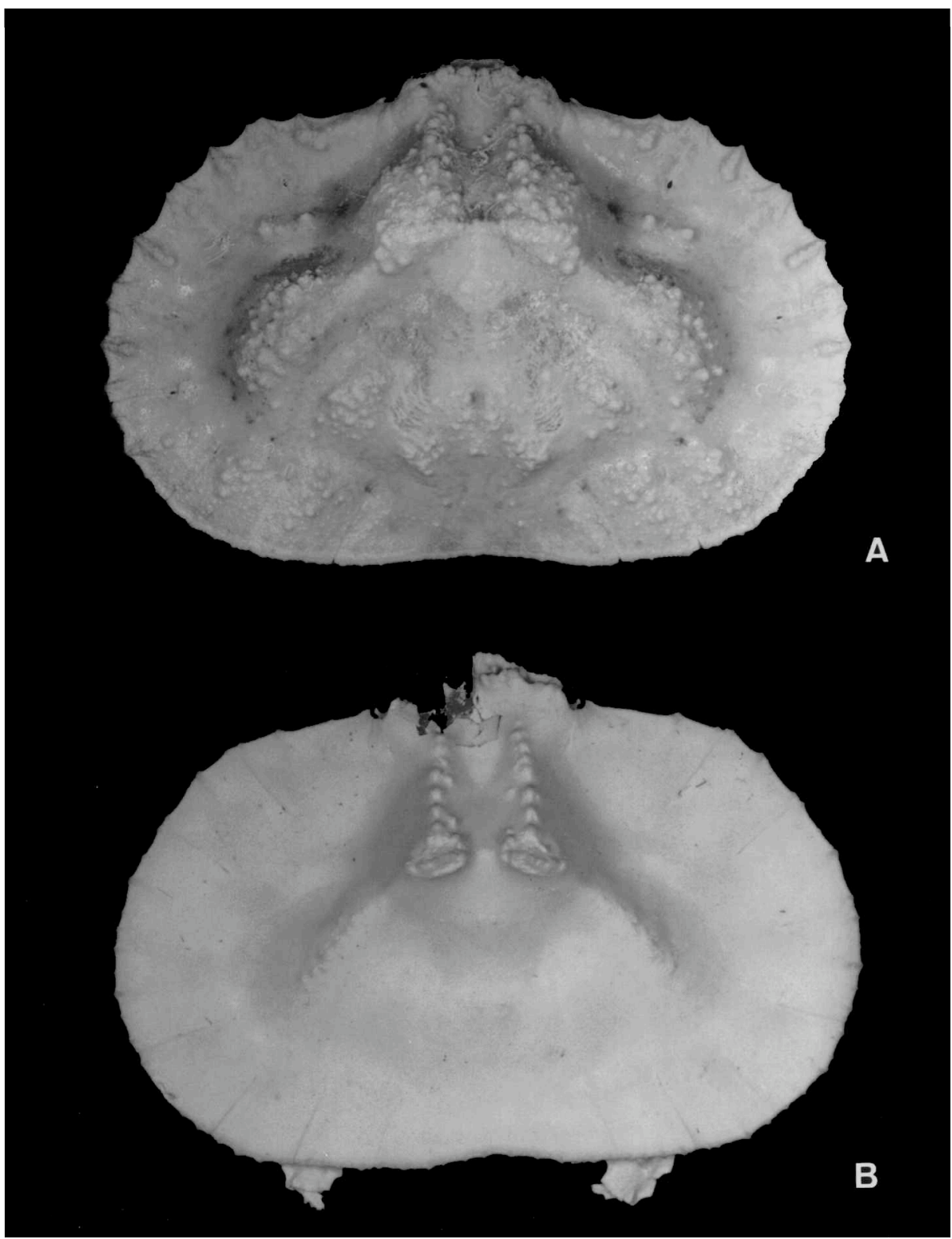

Fig. 1. Aethra scruposa (Linnaeus, 1764). A, female, 80.6 by $57.0 \mathrm{~mm}$, ZRC 1997.440, Cook Islands; B, juvenile male, 34.2 by $24.1 \mathrm{~mm}$, ZRC, Guam (left part of rostrum damaged).

Remarks. - The type of Cancer scruposus Linnaeus, 1764, still extant, is now conserved in the Natural History Museum of the University of Uppsala, and has the number "M.L.U. (Museum Ludovicae Ulricae) 21" (Holm, 1957: 56, table 7). The specimen (sex not known) is dried. 
Aethra scruposa, although reported from over a very wide geographic area, is in fact represented by just a few specimens. It is apparently not common, but this is probably due to its excellent camouflage and very cryptic habits.

Sakai (1976) notes that it occurs in rocky bottoms, in water of 35 to $200 \mathrm{~m}$ depth. Aethra scruposa, however, is certainly a coral reef species, hiding in sand. The author has observed a live aquarium specimen (now preserved, ZRC) collected from shallow waters in Sri Lanka. It is a slow and lethargic species, hiding under sand during the day. All presently examined specimens were obtained from or near reefs.

The taxonomy of $A$. scruposa and the closely allied A. scutata has been somewhat confused. Aethra scutata has been variously regarded as a subspecies of A. scruposa or as a valid species. Aethra scutata is certainly very close to A. scruposa, but can be separated by several subtle carapace features. Rathbun (1925: 552), citing from A. Milne-Edwards' (1868) detailed paper, commented that in A. scutata, the "... carapace less uneven and less rugose, and the ornamentation and fissures of the lateral borders more distinct". Because of these rather minor differences, workers like A. Milne-Edwards (1878) and Rathbun (1925) regarded A. scutata only as a subspecies. Garth (1958), while still regarding A. scutata as a subspecies of $A$. scruposa, nevertheless implied that it might be in fact a good species, commenting that the "... ultimate decision as to one species or two should be based on pleopod studies" (Garth, 1958: 470).

Guinot $(1966,1967)$ figured the G1 and G2 of A. scruposa, and there are a number of distinct features which strongly support her recognition of $A$. scutata as a distinct species. The $\mathrm{G} 1$ of $A$. scutata is relatively stouter, gently sinuous, and gradually tapering compared to that of A. scruposa, whose G1 is proportionately more slender, more distinctly curved outwards, and the distal part is sharply tapering (see Garth, 1958, fig. 12 vs. Guinot, 1967, fig. 39). In addition, the distal segment of the $\mathrm{G} 2$ in A. scutata is about half the length of the basal segment (Guinot, 1967, fig. 40) whereas in A. scruposa, the distal segment is subequal in length to the basal segment (Garth, 1958, fig. 12a).

Externally, however, A. scutata is indeed very similar to A. scruposa. The differences mentioned in the degree of ornamentation and depth of the fissures between $A$. scutata and A. scruposa by earlier authors are not reliable, these features being markedly variable in A. scruposa. The carapace of $A$. scruposa, however, is indeed more granulose, especially on the expanded parts of the carapace as well as in the branchial and gastric regions. In adult specimens, the proximal part of the anterolateral margin in A. scruposa usually slopes very gently and appears to be parallel or subparallel to the frontal margin. In S. scutata, the proximal part of the anterolateral margin slopes distinctly posteriorly. The 
longitudinal median groove on the front is distinctly more shallow in A. scutata, and is in fact, closer to the condition in A. edentata.

A juvenile specimen of $A$. scruposa examined from Guam (ZRC) is remarkably similar to the adult in carapace shape. Most of the gastric and branchial regions in this juvenile specimen, however, are much less rugose and granulose, appearing almost smooth; and the anterolateral margins are less crenulated (fig. 1B). The protogastric regions in the juvenile specimen is lined with an indistinct row of large, rounded granules and is neither as diffuse or as rough as that of adults (fig. 1B). The posterior margin of the chela (including the pollex) even in a specimen so small, is still quite distinctly dentate, with well defined sharp teeth. This specimen, comparable in size to larger specimens of A. edentata, supports the present contention that whether the posterior margin of the chela is distinctly dentate is a good character.

The known distributions of A. scruposa and A. scutata do not overlap as yet. Aethra scruposa has a very wide distribution and has been recorded from the east coast of Africa, Mauritius, India, Sri Lanka (ex Ceylon), parts of southeast Asia, Japan, China, New Caledonia, and Fiji (Guinot, 1966; Sakai, 1976; Dai \& Yang, 1991). It is now known from the Cook Islands and Guam (present records). Aethra scutata on the other hand, has been reported thus far only in the eastern Pacific, from Baja California, Mexico to Ecuador (Smith, 1869; Rathbun, 1925; Garth, 1958; present data).

Aethra scutata S. I. Smith, 1869 (fig. 2)

Aethra scutata S. I. Smith, 1869: 120; Guinot, 1966: 749, 751, figs. 1, 5; Guinot, 1967: 831, 835, 837, figs. 25, 28, 38 .

Oethra scruposa var. scutata A. Milne-Edwards, 1878: 170, pl. 31 figs. 2-2e.

Aethra scruposa scutata Rathbun, 1925: 552, pl. 195; Garth, 1958: 468, pl. Z3 figs. 12, 12a, pl. 53.

Material examined. - 1 juvenile male, 23.8 by $15.9 \mathrm{~mm}, 1$ juvenile female, 31.3 by $21.3 \mathrm{~mm}$, USNM 207834; Ensenada de los Muertos, Baja California; coll. S. H. Glassell, 24 January 1932.

Remarks. - Aethra scutata was described on the basis of one male specimen 56.6 by $35.3 \mathrm{~mm}$ from La Paz, Lower California, Mexico. The species has been figured in some detail by A. Milne-Edwards (1878) and Garth (1958).

For its affinities with $A$. scruposa, see discussion under that species.

Aethra edentata Edmondson, 1951 (figs. 3-5)

Aethra edentata Edmondson, 1951: 214, figs. 19, 20; Eldredge, 1967: 14; Ng \& Takeda, 1998: 7. 


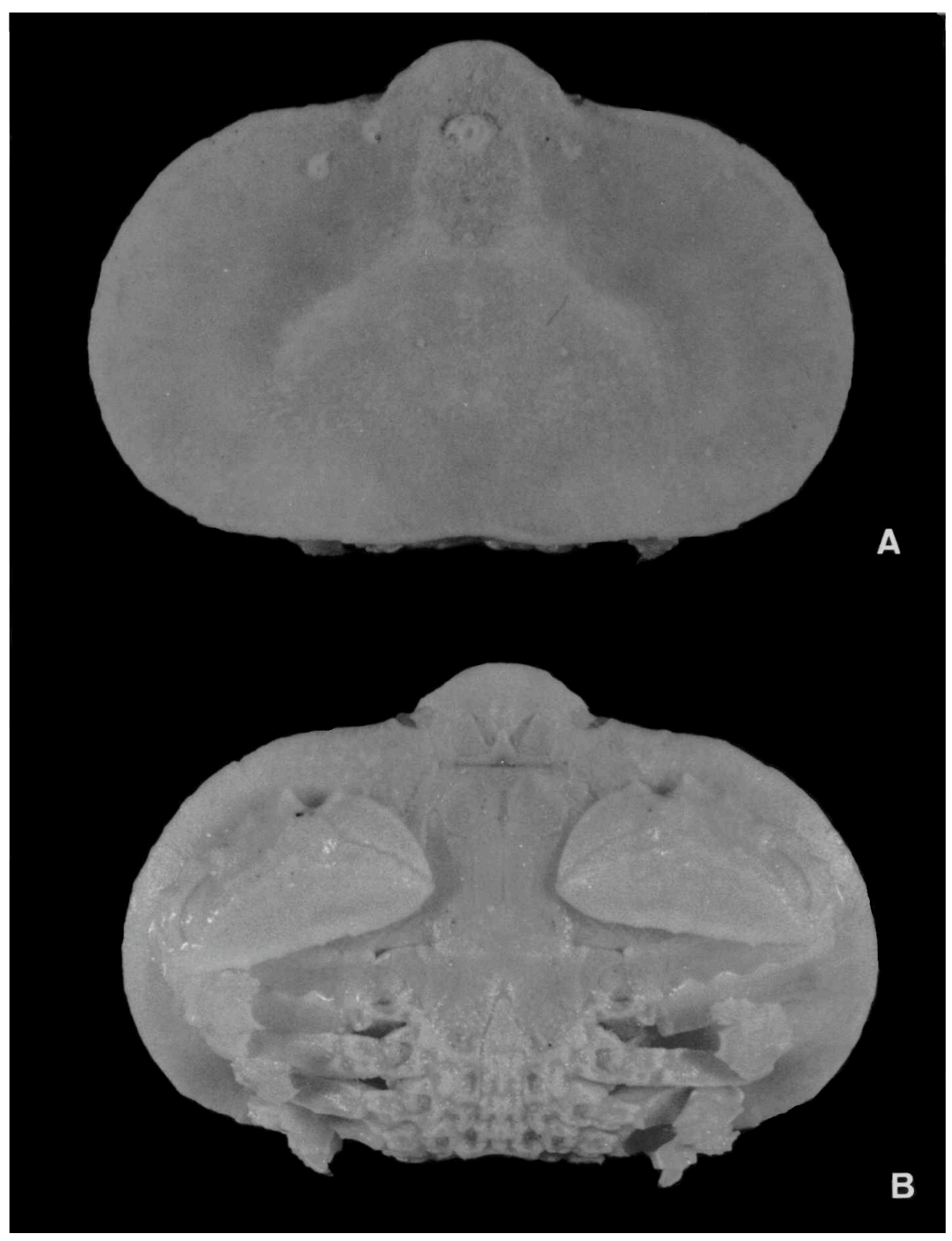

Fig. 2. Aethra scutata S. I. Smith, 1869, juvenile male, 23.8 by $15.9 \mathrm{~mm}$, USNM 207834, Baja California. A, dorsal view; B, ventral view.

Material examined. - Holotype, female, 30.0 by $19.6 \mathrm{~mm}$, BPBM 5561a; southwest coast of Oahu, Hawaii, 40-350 feet depth; coll. 8 August 1949; paratype, male, 26.8 by $18.2 \mathrm{~mm}$, BPBM 5561 b; same data as holotype; 1 female, 50.0 by 32.5 mm, BPBM 1979.384; coll. J. Earle; 1 male, ca. 37.8 by $23.4 \mathrm{~mm}$, right side of carapace broken, BPBM S7045; Oahu-Makua, Hawaii, 80 feet depth; coll. Hickam Sea Lancers, 4 July 1964; 1 female, 45.5 by 30.3 mm, BPBM 6996; off 


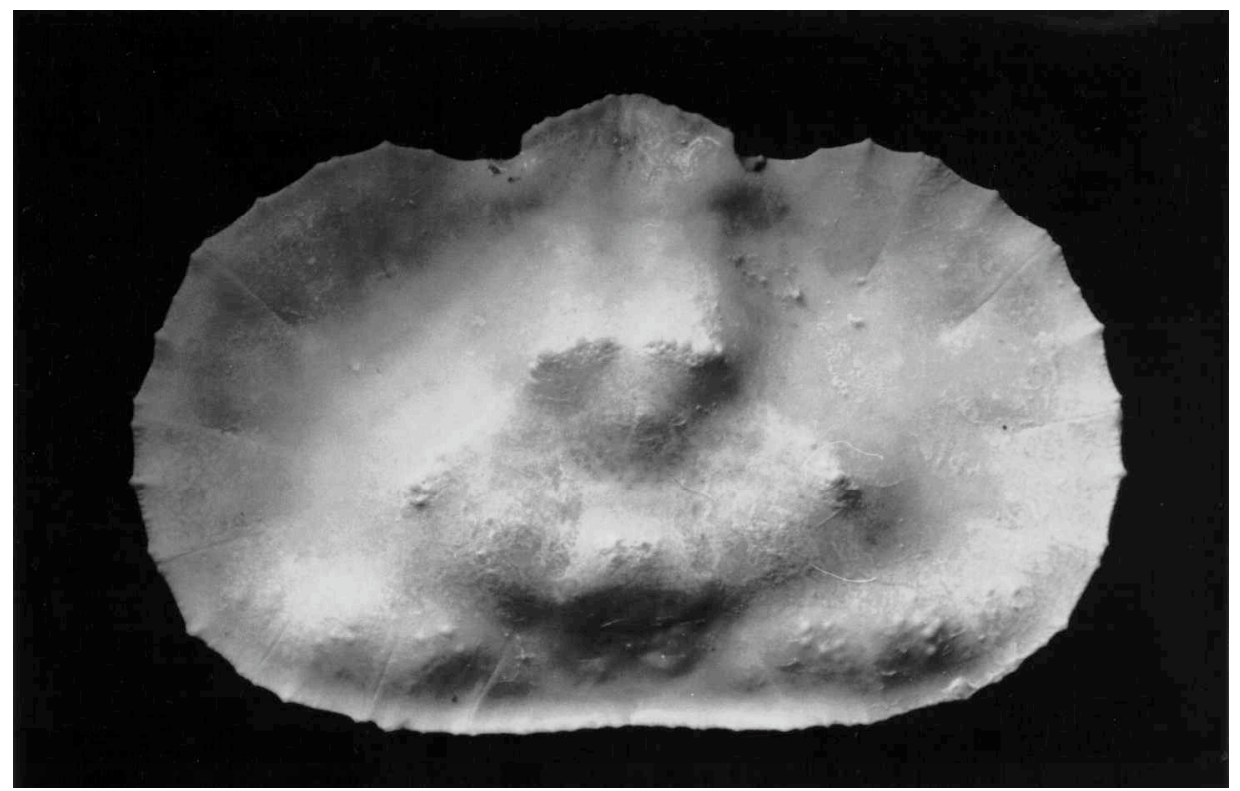

Fig. 3. Aethra edentata Edmondson, 1951, holotype, female, 30.0 by $19.6 \mathrm{~mm}$, BPBM 5561a, Hawaii.

Waikiki, Oahu, Hawaii, 10 fathoms depth; coll. D. P. Fellows, 12 September, 1963; 1 male, 22.7 by $15.7 \mathrm{~mm}$, BPBM 7051; off Ewa Beach, Oahu, Hawaii; coll. 30 May 1965; 1 male, 21.4 by 14.9 mm, USNM 209154; Waikiki, Oahu, Hawaii; coll. C. E. Cutress, 15 June 1953; 1 male, 39.2 by $25.9 \mathrm{~mm}$, USNM 291828; shallow sublittoral waters, west side, Taiohae Bay, Marquesas; coll. 16 September 1967; 1 female, 49.1 by 29.4 mm, NSMT; Ogasawara Islands, Japan.

Remarks. - Edmondson (1951) described A. edentata on the basis of one heterogeneous pair of specimens from Oahu, Hawaii. The two small specimens, however, are already adult in size. The label in the bottle lists both specimens as syntypes, but Edmondson (1951: 214) had already selected the larger female as the type (= present holotype).

Edmondson (1951) noted that A. edentata differed from congeners in "... the complete absence of dentition on the lower border of the palm of the cheliped. Also the rostrum appears to be more pronounced in the Hawaiian specimens" (Edmondson, 1951: 216-217). The BPBM has a reasonably good series of specimens of $A$. edentata and the species is apparently not as rare as the published literature would suggest. These specimens vary in size and show some variation. The ventral margins of the chela (including the pollex) are finely serrated and sometimes quite uneven, but never with well defined teeth. The frontal margin, when viewed dorsally, is somewhat variable in structure, from triangular to sub- 


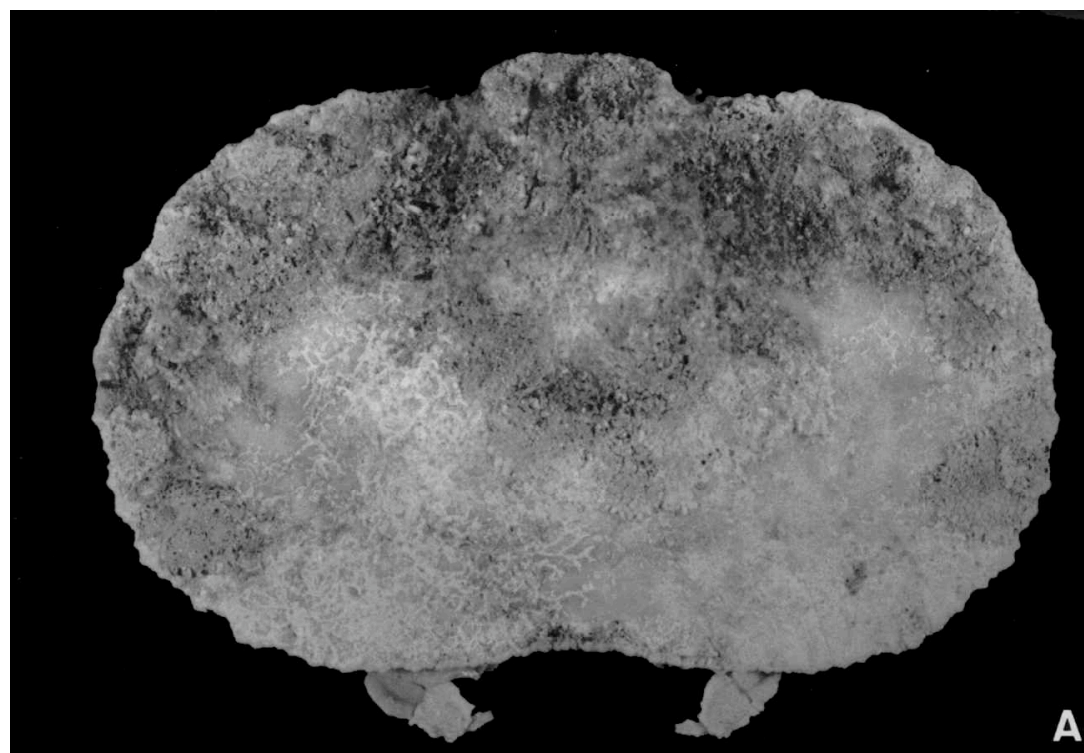

A

B

Fig. 4. Aethra edentata Edmondson, 1951, female, 39.2 by 25.9 mm, USNM 291828, Marquesas. A, dorsal view (carapace not cleaned); B, ventral view.

truncate in shape. The front is indeed somewhat longer than that of A. scruposa and A. scutata, but in A. edentata it is distinctly deflexed downwards.

It may be added that both $A$. scruposa and $A$. scutata are much larger species, with carapace widths easily exceeding $60 \mathrm{~mm}$. Small specimens of these two 


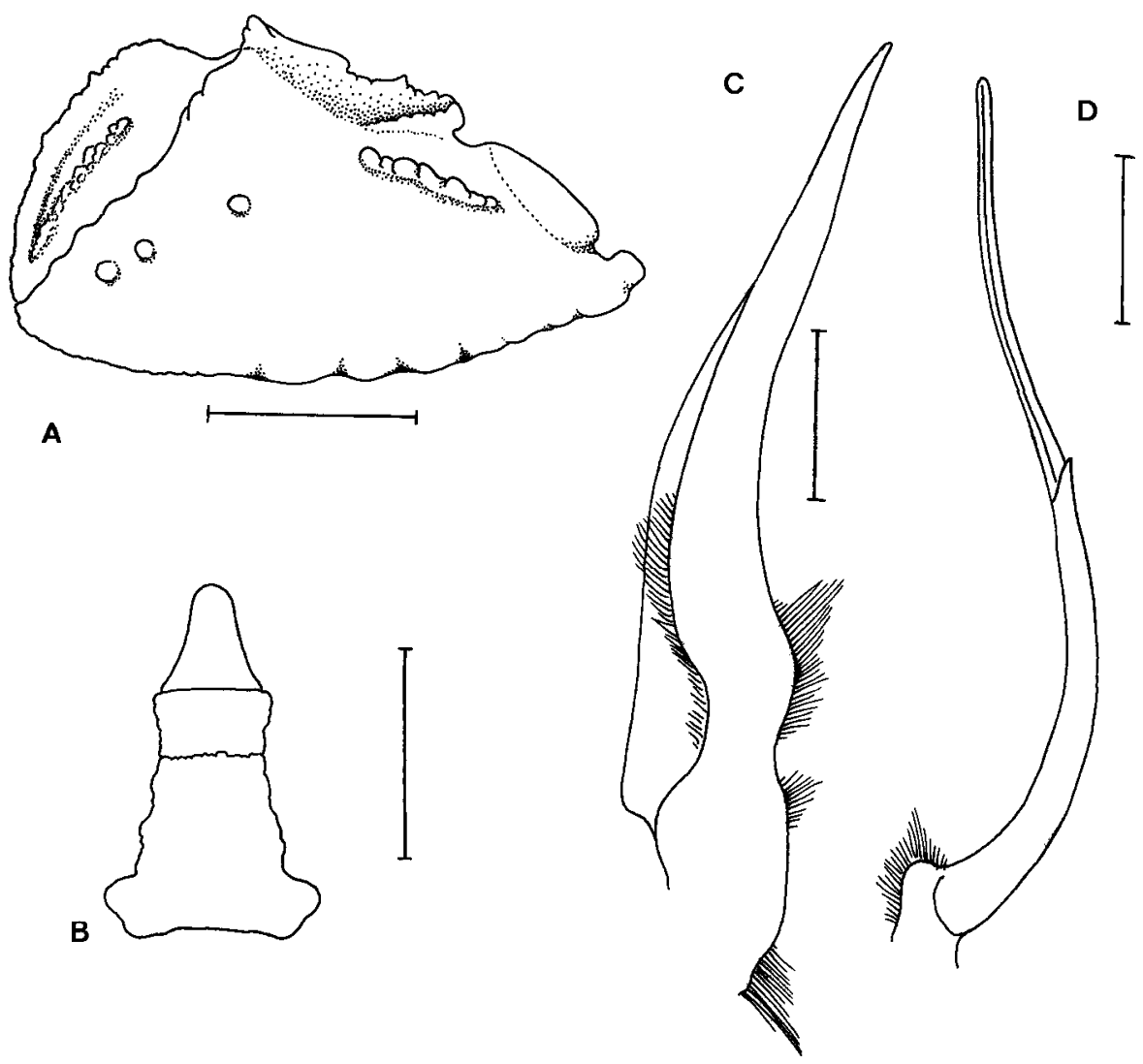

Fig. 5. Aethra edentata Edmondson, 1951, male, 39.2 by $25.9 \mathrm{~mm}$, USNM 291828, Marquesas. A, left chela; B, schematic figure of male abdomen, excluding surface ornamentation (segments 3-6 and telson); C, left G1; D, left G2. Scales: A, B = 5.0 mm; C, D = $1.0 \mathrm{~mm}$.

species less than $30 \mathrm{~mm}$ carapace width which have been reported or we have examined are still juveniles or immature.

The male pleopods of the species are figured here for the first time (fig. 5C, D). The key characters of the carapace and chela morphology as well as the features of the male abdomen and male pleopods of all the specimens agree very well for the specimens from Hawaii, Japan, and the Marquesas.

Aethra edentata was known only from Hawaii until recently when $\mathrm{Ng} \&$ Takeda (1998) recorded the species from the Ogasawara (= Bonin) Islands in Japan as well as from the Mariana Islands (Pagan and Guam). The present record from the Marquesas extends its range further westwards. 


\section{Aethra seychellensis Takeda, 1975}

Aethra seychellensis Takeda, 1975: 199, pl. 1.

Material examined. - Holotype, male, 57.0 by 39.8 mm, NSMT-Cr 4380; Seychelles Bank; coll. M. Amo, 25-30 December 1968.

Remarks. - This species is closely allied to A. scruposa, but can be immediately separated by the high, sublamelliform, posteriorly directed gastric projection on the carapace. I examined this specimen briefly during a visit to the NSMT in 1997, and this structure does not appear to be anomalous or a result of regrowth due to previous damage.

Takeda (1975) also noted that A. seychellensis can also be separated from A. scruposa by its strongly upturned posterolateral carapace margins and the rostrum (front) being simple, without a "double rim" (i.e., depressed medially with the margins appearing cristate). No specimen of A. scruposa we have examined (or seen in the literature) has the kind of upturned posterolateral and deeply concave posterior carapace margins present in A. seychellensis. The form of the rostrum, however, seems less useful as a diagnostic character as it varies slightly in A. scruposa, and the differences between that of A. seychellensis and those of some of the A. scruposa specimens we have examined does not appear very significant. In the specimens of A. scruposa we have examined, the rostrum varies, and the range of variation includes that seen in A. seychellensis. The deep longitudinal median depression present on the rostrum is a characteristic of A. scruposa and A. seychellensis. In A. scutata and A. edentata, the rostrum appears much flatter as the longitudinal median groove is shallower.

Aethra seychellensis is known only from one specimen from the Seychelles.

\section{KEY TO THE SPECIES OF AETHRA}

1. Posterior margin of the chela (including pollex) entire, serrated or uneven, but never with well defined sharp teeth .................. edentata (Hawaii, southern Japan, Marquesas)

- Posterior margin of the chela (including pollex) strongly dentate, with 5-8 well developed, well

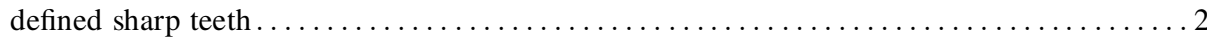

2. Median longitudinal groove on front shallow; G1 gently sinuous, distal part gradually tapering; G2 with distal segment about half the length of basal segment .... A. scutata (eastern Pacific)

- Median longitudinal groove on front deep; G1 slender, more distinctly curved outwards, distal part sharply tapering; G2 with distal segment about subequal in length to basal segment ....3

3. Gastric region with high, sublamelliform posteriorly directed projection; posterolateral and posterior carapace margins strongly upturned.............. seychellensis (Seychelles)

- Gastric region raised but without any projection; posterolateral and posterior carapace margins gently upturned or level........................ scruposa (Indo-West Pacific) 


\section{ACKNOWLEDGEMENTS}

The author is grateful to Lipke Holthuis for his help in establishing the correct authorship and year of publication of Aethra, and access to his excellent library. Charles Fransen was most helpful in sourcing out the relevant study material in Leiden. Lu Eldredge (BPBM), Masatsune Takeda (NSMT), Rafael Lemaitre (USNM) and Charles Fransen (RMNH) kindly allowed me access to the collections under their care, and their hospitality and help is much appreciated. Gustav Paulay kindly sent me comparative material from Guam. Tan Swee Hee kindly photographed the specimens.

\section{REFERENCES}

AlCOCK, A., 1895. Materials for a carcinological fauna of India. No. 1. The Brachyura Oxyrhyncha. Journal Asiatic Soc. Bengal, 64, (2 (2)): 157-291, pls. 3-5.

Colin, P. L. \& C. ARneson, 1996. Tropical marine invertebrates: 1-295. (Coral Reef Press).

DAI, A.-Y. \& S.-L. YAng, 1991. Crabs of the China Seas: 1-21, 1-608, pls. 1-74. (China Ocean Press, Beijing, Springer Verlag, Berlin).

DAI, A.-Y., S.-L. YAnG, Y.-Z. Song \& G.-X. Chen, 1986. Crabs of the China Seas. (China Ocean Press, Beijing). [In Chinese.]

Edmondson, C. H., 1951. Some central Pacific crustaceans. Occ. Pap. Bernice P. Bishop Mus., 20 (13): 183-243.

ELDREDGE, L. G., 1967. Catalog of invertebrate type specimens. Division of Invertebrates, Department of Zoology, Bernice P. Bishop Museum: 1-20. (Pacific Sci. Info. Cent., Hawaii).

FLIPSE, H. J., 1930. Oxyrrhyncha [sic]: Parthenopidae. Die Decapoda Brachyura der SibogaExpedition, VI. Siboga-Exped. Mon., 39c2 (112): 1-96.

GARTH, J. S., 1958. Brachyura of the Pacific coast of America. Oxyrhyncha. Allan Hancock Pacific Exped., 21 (1): i-xii, 1-499; 21 (2): 677-854, pls. A-Z, 1-55.

Guinot, D., 1966. Recherches préliminaires sur les groupements naturels chez les Crustacés Décapodes Brachyoures. I. Les affinités des genres Aethra, Osachila, Hepatus, Hepatella et Actaeomorpha. Bull. Mus. natn. Hist. nat., Paris, (2) 38 (5): 744-762.

— —, 1967. Recherches préliminaires sur les groupements naturels chez les Crustacés Décapodes Brachyoures. I. Les affinités des genres Aethra, Osachila, Hepatus, Hepatella et Actaeomorpha (suite et fin). Bull. Mus. natn. Hist. nat., Paris, (for 1966), (2) 38 (6): 828-845.

Holm, Å., 1957. Specimina Linnaeana i Uppsala bevarade zoologiska samlingar från Linnés tid. Uppsala Univ. Årsskr., 6: 1-68.

INTERNATIONAL COMMISSION ON ZOOLOGICAL NOMENCLATURE (ICZN), 1985. International Code of Zoological Nomenclature. Third Edn. Adopted by the XX General Assembly of the International Union of Biological Sciences. International Trust for Zoological Nomenclature, in association with the British Museum (Natural History), London: 1-338.

LAMARCK, J. B. P. A., DE, 1818. Histoire naturelle des animaux sans vertébrés, presentant les caractères généraux et particuliers de ces animaux, leur distribution, leurs classes, leurs familles, leurs genres, et la citation des principales espèces qui s'y rapportent; précédée d'une introduction offrant la détermination des caractères essentiels de l'animal, sa distinction du végétal et des autres corps naturels, enfin, l'exposition der principes fondamentaux de la zoologie 5: 1-612. (Paris). 
LAtreille, P. A., 1816a. Crustacés, Arachnides et Insectes. In: G. Cuvier, Le Règne Animal, distribué d'après son organisation, pour servir de base à l'histoire naturelle des animaux et d'introduction à l'anatomie comparée, 3: i-xxix, 1-653. (Paris).

— - 1816b. Corrections et additions [to Tome III]. In: G. CuvIER, Le Règne Animal, distribué d'après son organisation, pour servir de base a l'histoire naturelle des animaux et d'introduction a l'anatomie comparée, 4: 174-179. (Paris).

— - 1816. Calappe, Calappa, Fab. Nouveau dictionnaire d'histoire naturelle, appliquée aux arts, à d'agriculture, à l'économie rurale et domestique, à la médecine, etc. Par une société de naturalistes et d'Agriculteurs. Nouvelle édition presqu'entièrement refondue et considérablement augmentée; avec des figures tirées des trois Règnes de la Nature, 4: 601-602. (Paris).

LinNAeUS, C., 1764. Museum S:ae R:ae M:tis Ludovicae Ulricae Reginae Svecorum, Gothorum, Vandalorumque, etc.: 1-720. (L. Salvius, Holmiae).

Manning, R. B. \& L. B. Holthuis, 1981. West African brachyuran crabs (Crustacea: Decapoda). Smithsonian Contrib. Zool., 306: 1-379.

Mathews, G. M., 1911. On some necessary alterations in the nomenclature of birds. Part II. Nov. Zool., 18 (1): 1-18.

MiERS, E. J., 1879. Descriptions of new or little-known species of maioid Crustacea (Oxyrhyncha) in the collection of the British Museum. Ann. Mag. nat. Hist., (5) 4: 1-28, pls. 4, 5.

Milne-EdwARDS, A., 1878. Études sur les Xiphosures et les Crustacés de la région mexicaine. In: Mission scientifique au Mexique et dans l'Amérique centrale, 5: 121-184, pls. 21-27, 29, 30.

MiLne EdWARDS, H., 1834. Histoire naturelle des Crustacés, comprenant l'anatomie, la physiologie et la classification de ces animaux, 1: i-xxxv, 1-468. (Paris).

NG, P. K. L., 1994. The citation of species names and the role of the author's name. Raffles Bull. Zool., 42 (3): 509-513.

NG, P. K. L. \& M. TAKedA, 1998. Aethra edentata Edmondson, 1951 (Crustacea, Decapoda, Brachyura, Parthenopidae), new records for the Izu-Mariana Arch. Bull. natn. Sci. Mus., Tokyo, (A, Zool.) 24 (1): 7-10.

Rathbun, M. J., 1897. A revision of the nomenclature of the Brachyura. Proc. biol. Soc. Washington, 11: 153-167.

— - 1925. The spider crabs of America. Bull. U.S. natl. Mus., 129: i-xx, 1-613, pls. 1-283.

Roux, C., 1976. On the dating of the first edition of Cuvier's Règne Animal. Journ. Soc. Biblyphy. nat. Hist., 8 (1): 31.

SAKAI, T., 1976. Crabs of Japan and the adjacent seas. 1 [English text]: i-xxix, 1-773, figs. 1-379, maps 1-3; 2 [Japanese text]: 1-461, figs. 1-2; 3 [atlas]: 1-61, pls. 1-251. (Kodansha, Tokyo).

SERÈnE, R., 1968. The Brachyura of the Indo-West Pacific region. In: Prodromus for a check list of the non-planctonic marine fauna of South East Asia. Singapore natn. Acad. Sci., Spec. Publ., 1: 33-112.

SMith, S. I., 1869. Descriptions of a new genus and two new species of Scyllaridae and a new species of Aethra from North America. American Journ. Sci., (2) 48: 118-121.

StimPSON, W., 1858. Prodromus descriptionis animalium evertebratorum quae in expeditione ad Oceanum Pacificum Septentrionalem a Republica Federata missa, Cadwaladaro Ringgold et Johanne Rodgers ducibus, observavit et descripsit - Part V, Crustacea Ocypodoidea. Proc. Acad. nat. Sci., Philadelphia, 9: 93-110.

TAKedA, M., 1975. Preliminary description of a new crab of the Parthenopidae from the Seychelles Bank. Bull. natn. Sci. Mus., Tokyo, (A, Zool.) 1 (4): 199-202, pl. 1. 